\author{
DOI $10.23859 / 2587-8352-2018-2-1-3$ \\ UDC 93
}

\author{
Katalin Juhász \\ Research Centre for the Humanities, \\ Hungarian Academy of Sciences, Budapest \\ juhasz@etnologia.mta.hu
}

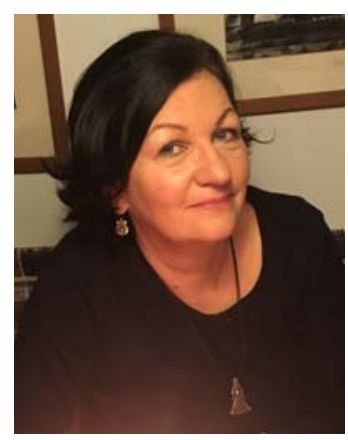

\title{
Pollution for cleanliness? Lessons from an ethnographic research on the rural use of water for hygienic purposes
}

Abstract. Several evidences from ethnographic research have shown how strongly water consumption and hygienic practices are influenced by hydrogeological conditions and the availability of water resources. On the contrary, dust, dirt, rubbish are the things we are trying to get rid of during the cleaning process. The traditional rural way of life was closely connected with nature and it worked as an almost complete recycling system. The water coming from natural resources was used for cleaning the body, clothes, dishes and the house as little as possible. Only the simplest substances like ash $(\mathrm{KOH})$, soda $\left(\mathrm{Na}_{2} \mathrm{CO}_{3}\right)$ or home-made soap from animal fat $(\mathrm{NaOH})$ were used as detergents, which did not do any harm when it was recycled into nature together with minimal household waste. The careful attitude to water had a well-developed order, as a result of which people lived in harmony with their natural environment for centuries. However, this harmony was broken and turned into the opposite direction with the arrival of urbanisation and consumerism: so that we can match the latest hygienic standards (ideals) artificially generated by the market, we use more and more water and chemicals to reach the desired cleanliness, so we become cleaner and cleaner, however more and more pollutants are returning to the environment.

Keywords: hygiene, Hungarian history, traditional peasant culture, water usage, waste recycling

May God grant that I treat everything with orderly due love (my italics K.Ju.), tearing off the earth and turning it to heaven; so that I could use the blessings of the world so much as if I did not use them. Do it so that by an inner feeling I can distinguish those that I need, from those that are harmful to me, that the transitory takes me for a short time and only to the extent necessary, and that only eternal realities attract my enduring interest.

Bernard of Clairvaux 


\section{Introduction}

Ethnography studies traditional culture, foremost peasant culture of villages and rural settlements. Its main method is field research, detailed description of material and spiritual culture, customs, behavioural norms, as well as analysis of written documents and information from historical sources ${ }^{1}$. Two branches of our science studying material and spiritual culture, are engaged in relations between man and water. Scientists have established that from the point of view of the survival of the human race, the strategic question at all times - both for understanding the past and for predicting the future - was water, and culture helps us understand it in all its complexi$t^{2}$. Human civilization since its inception has formed a multi-level system of relations with the surrounding world, especially with those phenomena that are necessary for its life. Water as a basic condition of life, as the main means of maintaining purity, plays an important role not only in everyday practice, but also in symbolic purificatory and healing rituals or magic.

In the folklore of the peoples of the world, water, due to its physical and chemical properties, has similar meanings and functions. One part directly follows from everyday practices of using water, from fishing to eating, from washing to a transport artery. Water is often used in purifying rituals and rituals associated with fertility, which is reflected in myths, cosmogonic legends, the beliefs of many peoples. The motif of "living water", the phenomenon of water as a carrier of life, covering historical epochs and cultures, belongs to the basic layer of the common civilization heritage.

Hungary is known all over the world for its mineral waters and medicinal springs. One of the first synthetic works on this subject is George Wernher's treatise "On the Wondrous Waters of Hungary", , published in 1549 in Basel, which for half a century has survived six editions and spread throughout Europe. Baron Sigismund von Herberstein (1486-1566), who is called in historiography the "first career diplomat" of

1 On the concept of ethnography / ethnology, its history and individual directions, see: Tokarev S.A. Tokarev S.A. Istoriya russkoj ehtnografii (Ddooktiabr'skij period) [The history of Russian ethnography (pre-October period)]. Moscow, 1966; Idem. Istoki ehtnograficheskoj nauki [Origins of ethnographic science]. Moscow, 1978. On the Hungarian material, see: Kósa L. A Magyar néprajz tudománytörténete. Budapest, 2001. On the tasks facing modern science, see: Campbell E., Lassiter L.E. Doing ethnography today: Theories, methods, exercises. West Sussex, 2015.

2 In 2008, as part of the celebration of the Day of Hungarian Science at a conference in the Hungarian Academy of Sciences, several speakers considered this range of problems. See: A víz kultúrája / Szerk. E. Bartha, R. Keményfi, V. Lajos. Debrecen, 2010 (Studia folkloristica et ethnographica. 55).

3 The electronic version is available, for example, on the website of the Austrian National Library. See: Wernher G. De admirandis Hungariae aquis hypomnemation. sine dato et loco. $20 \mathrm{p}$. Available at: http://digital.onb.ac.at/OnbViewer/viewer.faces?doc=ABO_\%2BZ103578602 (retrieved 15.10.2017). 
Central Europe, in the famous "Notes on Muscovy" ${ }^{4}$ referred to Werner's book. Together with other archival documents and published works, this treatise remains the most important source of historical hydrology and historical ecology, contains unique information on the methods of water use at that time. The environmental history in Hungary was isolated in the form of an auxiliary scientific discipline in the 1980s (separated from historical geography) ${ }^{5}$. Ágnes Várkonyi played a decisive role in it, she not only actively studied historical and ecological subjects, but also compiled a collection of articles, which became the first textbook on this discipline ${ }^{6}$.

In my article, I will focus only on one narrow segment of water-related phenomena and images: the results of an ethnographic study of the water usage for hygienic purposes in Hungary.

\section{Main body}

Sources of replenishment of water in the Carpathian basin.

Many ethnographic studies are devoted to the impact of the hydrogeological situation, access to water for lifestyle and survival strategies, as well as how a person utilized took advantage of natural water resources without changing them. These are, above all, the works of Bertalan Andrásfalvy, Balázs Borsos and Gergely Krisztián Horváth ${ }^{7}$. Subject ethnography has studied and documented ways to extract, transport and use water ${ }^{8}$ since its inception. The hydrological situation in the Carpathian Basin, referring to the Danube catchment area, differed in the possibilities of drainage before being contaminated. Sources of replenishment of water in the Carpathian Basin:

4 Gerbershtein S. Zapiski o Moskovii. [Zapiski o Moskovii]; Pod red. A.L. Khoroshkevich. Moscow, 2008. Vol. 1. (Pamyatniki istoricheskoj mysli [Monuments of historical thought]).

5 See also: A táj változásai a Honfoglalás óta a Kárpát medencében: a Gödöllőn 1996. június 24-26. -án megtartott tudományos konferencia kiadványa; Szerk. Gy. Füleky. Gödöllö, 1997.

6 Táj és történelem - Tanulmányok a történeti ökológia világából; Szerk. A. R. Várkonyi. Budapest, Osiris, 2000.

${ }^{7}$ See: Antropogén ökológiai változások a Kárpát-medencében; Szerk. B. Andrásfalvy, G. Vargyas. Budapest, 2009; Borsos B. Rivers, Marshes and Farmlands. Research Perspectives on the Ecological History of Hungary through Examples of Bodrogköz (NE-Hungary). Hungarian Studies, 2009, vol. 23, no. 2, pp. 195-210; in Bulgarian translation see: Borshosh B. Reki, blata i zemedelski zemi. Izsledovatelski perspektivi za ekologichnata istoriya na Ungariya chrez primeri ot Bodrogk'oz, Severoiztochna Ungariya. B 'lgarski folklore, 2011, T. 37, no. 1, s. 110-127; Víz és társadalom Magyarországon a középkortól a XX. század végéig; Szerk. G. K. Horváth. Budapest, 2014.

${ }^{8}$ The summarizing, charted result of this large-scale study was the compilation of the "Hungarian Ethnographic Atlas". See: Füzes E. Kutak tájitípusai. Magyar NéprajziAtlasz IV; Szerk. J. Barabás. Budapest, 1989, pp. 276-281. On the dependence of water use on the hydrological situation see: Juhász K., Szabó Z.G. A hidrogeológiai viszonyokés a vízhasználat összefüggései, különös tekintettel a Balaton-felvidék településeire. Tiszta sorok. Tanulmányok a tisztaságról és a tisztálkodásról; Szerk. K. Juhász. Budapest, 2009, pp. 48-65. 
- Surface sources:

- rivers, streams,

- lakes.

- $\quad$ Sources replenished from the soil:

- karst springs,

- groundwater and confined aquifer.

- Subterranean sources:

- Groundwater,

- confined aquifer

- karst water.

- Precipitation:

- rainwater,

- thawed snow, ice.

Surface water until the late 1960's, and in some places to this day, served as an important source of water for the local population. There is a lot of information that in the first half of the twentieth century a significant part of the water for household needs and even drinking was taken from surface sources - rivers, streams, lakes.

In places where karst springs, ground waters and confined aquifer emerged, a socalled "csorgo" was built, that is a well in the form of a covered construction with a water-lifting mechanism to facilitate the extraction of water. Of the three types of underground sources - ground water, confined aquifer and karst waters - the groundwater was of decisive importance in the Carpathian basin. Because of the shallow occurrence, they were extracted from so-called excavated wells (Figure 1), which are considered to be the oldest type. Their construction did not require any outstanding strength, or special knowledge, but the water in them was too stiff and / or dirty.

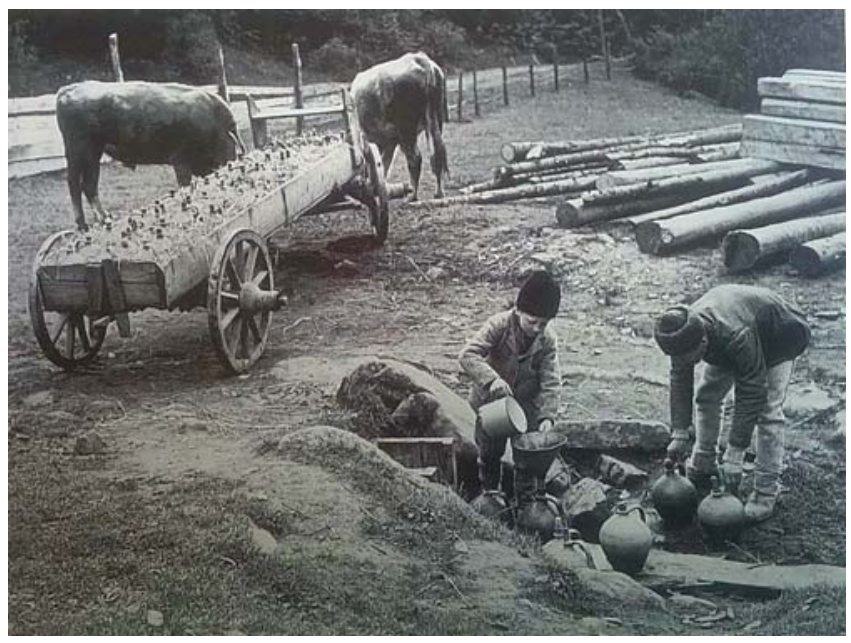

Figure 1. Father and son collect water in a jug at the well to sell it to the inhabitants of remote villages. The village of Harghita Băi (in Hungarian Hargitafürdő) in Romania. Unknown photographer from the 1940s. 
For the installation of the so-called drilling wells, it was necessary to drill the first layer of the earth; moreover, that's also true for artesian wells, in which water comes to the surface under pressure. Construction of a drilling well required high costs, so such structures are found in the courtyards of wealthy owners or in the canter of the settlement - for the needs of all residents. In different parts of Hungary, wells differ in the way they take water and the shape of a well house (building above the well itself). This issue was further specified in the Hungarian Ethnographic Atlas.

Human intervention (river regulation, depletion of continental waters, drainage of marshes, mining of minerals) changed the height of the groundwater table significantly (primarily in the two regions of Alfold and the mining regions): it fell by several meters, which also affected the well's depths.

In addition to the above listed sources of water, rainwater was used actively, such as thawed snow in the winter, especially for personal hygiene. Rainwater and thawed snow are softer (they foam the soap easily), having better cleansing properties and not irritating the skin, so they are clean and easy to get.

Until the 1970s the listed ways of water extraction determined water usage for personal hygiene throughout Hungary, although large cities were exceptional. These circumstances served simultaneously as "technical" brakes in changing the practice of maintaining cleanness and hygiene. Only in the early 1960s infrastructure of the Hungarian province began to approach the level, which allowed a thorough change in the practice of cleaning, washing and doing laundry. Therefore, back in the 1970s and 80 s one could observe more archaic forms of maintaining cleanliness and hygiene in the villages.

Starting from the turn of the nineteenth and twentieth centuries and up to now, the customs of maintaining cleanliness and hygiene can be divided into five models. All of them are, in one way or another, connected with the process of "embourgeoisement", (in Hungarian "paraszti polgárosodás") ${ }^{9}$, which Marxist historiography considered in the categories of transition from feudalism to capitalism, and today the most accurate term will probably be "a [capitalist] modernization of the village". It is a

\footnotetext{
${ }^{9}$ Historian Peter Hanák distinguished "extensive" and "intensive” management (see: P. Hanák Magyarország társadalma a századforduló idején. Magyarország története 1890-1918; Szerk. P. Hanák. Budapest, 1988, pp. 403-516), while the ethnographer László Kósa in the process of modernizing the peasantry emphasizes the transition stage (see: Kósa L. Paraszti polgárosulás és a népi kultúra táji megoszlása Magyarországon (1880-1920). Debrecen, 1990). The process of the formation of bourgeois society in Hungary was forcibly interrupted in 1948 with the Communists coming to power. Because of the penetration of the Western consumption culture, Hungary became the "most cheerful barrack" in the Eastern bloc (see: Juhász K. Запах тела и аромат чистоты в культуре обитателей «самого веселого барака»: Венгрия, 1960-1989 годы. [Body-OdourCleanliness within the "Happiest Barracks", Hungary 1960-1989]. Теория Моды [Theory of Fashion], Nr. 26, (Зима) 2012-13. 339-363, 457. Available at: http://www.nlobooks.ru/node/2978 (2013)
} 
process of socio-economic, cultural, ideology, and everyday lifestyle changes that began in the mid-nineteenth century, during which the feudal peasantry turned into agricultural workers of the period of capitalism. As a result, peasant culture underwent fundamental changes, some of its elements were completely lost. Five models, corresponding to the five stages of development, represent periods, the boundaries between which are blurred, and the changes occurred both geographically and vertically, i.e. in separate social groups and even families: elements belonging to different models co-existed in different periods of time and in the same household, in accordance with the laws of "parallel asynchronity" ${ }^{10}$ (see Table).

Table

\section{Stages of modernization of the village and changing in hygienic practices}

Stages of modernization of the village
according to P. Hanák and L. Kósa
P. Hanák
- Modernization of the village as an external factor
- Modernization of the village as an internal need of
the individual
$\underline{\text { L. Kósa }}$
- Archaic state
- Beginning of village modernization (transitional pe-
riod)
- A peasant as an agricultural worker (he ceases to be
a peasant)

\section{Models of hygiene practices $^{11}$ :}

- Archaic peasant

- Peasants adopt elements of urban life

- Village of the modernization period

Since the late 1970s:

- "Consumer socialism"

- Consumerism (the differences between town and country disappear)

It would be more correct to consider each model in the form of such a theoretical construction that at one or another epoch, characterizes the practices of maintaining the cleanliness and hygiene of the largest number of rural inhabitants in its main features.

The main means of cleanliness and hygiene:

1. Water (the way it is produced, the volume and quality of consumption).

10 The concept of "parallel asynchrony" was introduced by Hermann Bausinger (see: Bausinger H. "Párhuzamos különidejüségek". A néprajztól az empirikus kultúratudományig. Ethnographia 100,1989 , pp. 24-37). In the context of cleanliness, V. Lajos already talks about "complex asynchrony", when more than two traditional models are merged in one household. See: Lajos V. Testek - tisztaság - modernitás. Kulturális és társadalmi összefüggések Moldvában a «báje» kapcsán. Tisztasorok. Tanulmányok a tisztaságról és a tisztálkodásról; Szerk. K. Juhász. Budapest, 2009, pp. 159-171.

${ }^{11}$ Juhász K. Meg is mosakodjál! Higiénia a 20. századi falun. Have Wash! - Hygiene in the 20th Century Village Szentendre, 2006. 
2. Place and equipment for maintaining cleanliness (washbasin, bathroom, dishes).

3. Detergents for different parts of the body.

4. Types of towels and related garments (bath robe).

5. Means for body care, cosmetics for different parts of the body.

Further in the article I will show the most characteristic features of the five models, paying special attention to the use of detergents - water and so on (in accordance with the above five points). The framework of the article does not allow us to consider the tradition of maintaining cleanliness in detail ${ }^{12}$, so I will focus on the most important for each model. Generalizing tables will help to trace the changes in the basic concepts that describe the cleanliness, hygiene means and customs from the 19th century to the present day.

\section{Archaic peasant hygiene practices (until the 1910s).}

The most ancient peasant practices of maintaining cleanliness are rooted in the depths of centuries. Although, according to sources, ancient Hungarians during the period of "finding their homeland" (settling in the Carpathian Basin in the 9th century) were able to install "steam cabins"13, and in the Middle Ages the landlords sometimes allowed their dependent peasants to use bathing facilities located in the estate; in the Hungarian peasant tradition there is nothing like a Russian bathhouse or a Finnish sauna.

Depending on the natural conditions, the population everywhere extracted water for drinking and household needs from surface sources or shallow wells dug by hand tools. In the second half of the 19th century, the quality of water improved due to wells of deep drilling and new water-lifting devices, later - artesian wells, but all this did not affect the volume and methods of water consumption. The means of water transfer formed a lot of local forms and names ${ }^{14}$. The common thing about them is that at one time one person could transfer water in the volume of daily demand, less often - two people. The water was carried in ceramic jugs, water bottles, wooden buckets, held in hands or hung in pairs on the crossbeam (Figure 2). Water was stored in the same vessels in which it was carried. If a lot of water was required, and its source was far away, barrels and tubs were filled with water, covered with boards, so

12 The first two models of maintaining cleanliness and hygiene are discussed in detail in the book (see: Juhász K. Meg is mosakodjál...), a review of all five models is given in the article (see: Juhász K. Body - Identity - Society: Concepts of the Socially Accepted Body in the 20th Century Hungarian Rural Areas. Acta Ethnographica, 2016, vol. 61, no. 2, pp. 283-312).

13 G. Csiffáry writes that the ancient Hungarians washed themselves in tents in a manner like a Finnish sauna: first they sweated in steam, emanating from stones, poured over with boiling water, rubbing and patting themselves on the body, then splashing in icy water. See: Csiffáry G. Régi Magyar fürdövilág. Budapest, 2004, pp. 41-61.

${ }^{14}$ Füzes E. Kutak táji típusai. Magyar Néprajzi Atlasz IV; Szerk. J. Barabás. Budapest, 1989, pp. 276-281. 
that the water would not splash, loaded onto carts and so delivered to the destination. Rain water was collected in containers (wooden and concrete barrels and tubs), placed under the downspouts. When there was no rain, they were regularly dried, so that the water did not spoil in them. In houses covered with reeds or straw, rainwater was not collected: because there were no downspouts. They collected it in meadow ditches, where it remained clean for a long time. The water was needed for washing the head, shaving, bathing a child, and if it was not lacking, then for doing laundry. In winter, snow taken in a clean place was thawed and used just like rainwater. The water extracted from a well was stored in portable vessels, two or three buckets, jars, placed on a water bench in the kitchen (Figure 3). Usually the vessels were covered to prevent infection or insects from entering the water, and it was scooped up with a mug, from which, if necessary, people drank. As a rule, there was a little more water in the house than the daily demand, because the water only went once a day. The daily rate, depending on local customs, was about 10-30 litres.

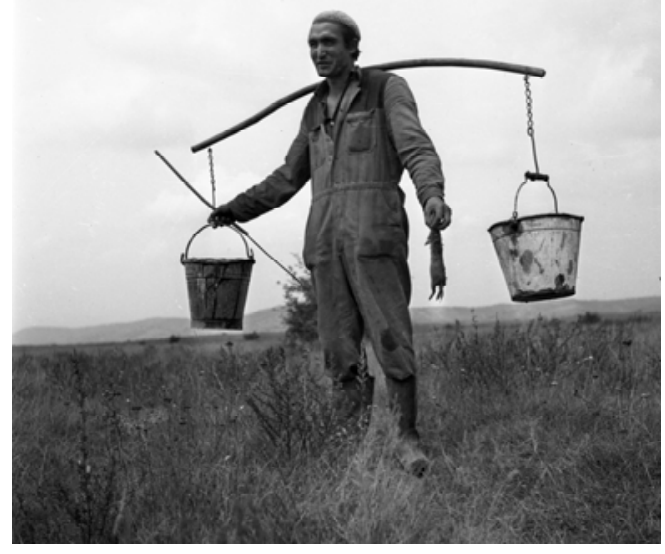

Figure 2. Carrying pole. Photo T. Urban, 1977.

Online Photoarchive Fortepan, No 15983

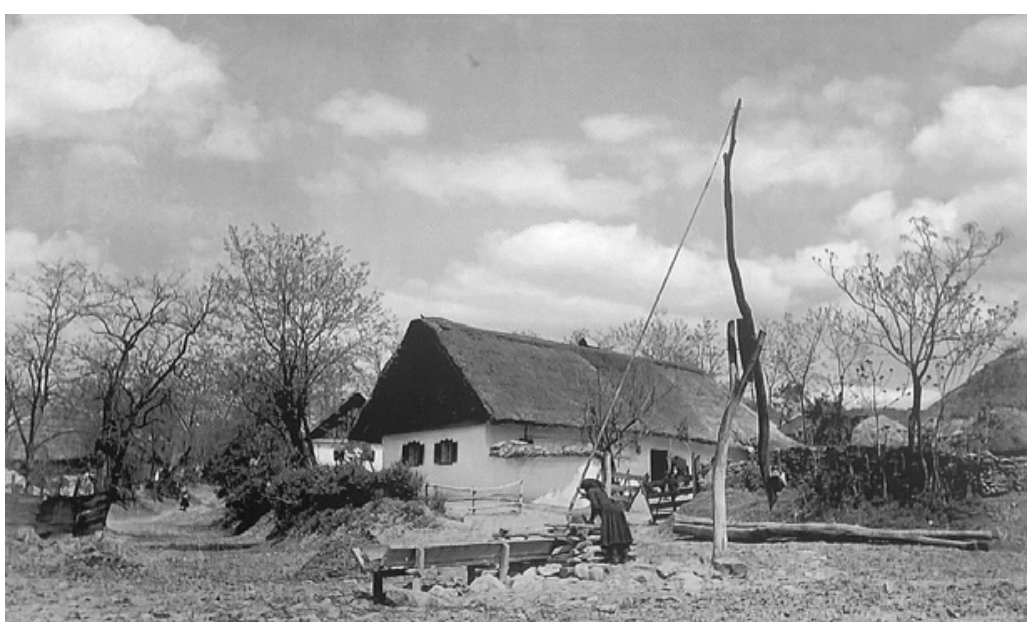

Figure 3. The outskirts of Tard village (Northern Hungary) with a well-crane. Unknown photographer from the 1930s 
If you compare the modern standards, the hygienic needs of the villagers were minimal: protection against parasites (lice, scabies) and the absence of dirt on visible parts of the body. Smells were not given much importance, the smell of a barn or stables, sweat and, in general, any fragrance emanating from the body was considered natural. The features of the dwelling (kitchen stoked "black", clay floors), clothes made from rough homespun linen, did not allow and did not require frequent and thorough cleaning and washing, the ways and regularity of which have changed over the centuries. Hygienic procedures in the house did not have any specific place. If the weather allowed, they preferred to wash outdoors: on the porch, at the well, in a secluded corner of the courtyard.

In the winter, people crowded in smoky, stuffy houses, did not wash at all, except for the symbolic morning wash ${ }^{15}$. With the onset of spring, on the first warm days they hurried to the rivers and lakes to wash off the dirt accumulated during the winter. As one of the informants said: "Our underwear has turned black with dirt". At the latest in the last week of the Lent, Easter Holy week, they washed from head to toe, cleaned up in the house and yard, tidied up ${ }^{16}$. For washing and shaving, only household soap was used. The head was not washed at all or very rarely (once or twice a year) by potash, instead of it, the hair was heavily greased to protect it from lice ${ }^{17}$. When washing, they were treated with a minimum amount of water (Figure 4), for the sake of economy they wiped themselves with a damp rag or poured out of the mug. Water, remaining on the body, naturally evaporated; there was almost no dirty water left after washing. Adults washed rarely and did this, as a rule, for medical purposes. Repeated use of water after washing was not uncommon: it was first used to do the laundry, then dirty water was used for irrigation or added to livestock feed. For washing the face and body unsalted pork fat, milk and butter were used, but these personal hygiene products at best were resorted to by girls for marriage.

15 They said: "If you do not wash yourself in the morning, you go around in the face of the devil". There was a custom to pray during morning cleansing.

16 On the morning of Good Friday, the day when Jesus died, it was customary throughout the country to wash "in silent water", i.e. in complete silence people walked to the nearest pond, stream, river and there they washed their faces, less often - they bathed, even less often - they bathed animals to be healthy all year round. See: Tátrai Zs. Aranyos víz szótlan víz. Tanulmányok a tisztaságról és a tisztálkodásról; Szerk. K. Juhász. Budapest, 2009, pp. 271-293.

17 For example, district doctor Maximilian Hölbling wrote in 1845: "And they [the women], and some men lubricate the hair abundantly with fat, and those who are not used to this can vomit, especially in the summer, when the droplets of fat drip down cheeks. The peasants consider this beautiful and boast that the Hungarian is not as dirty as the German". 


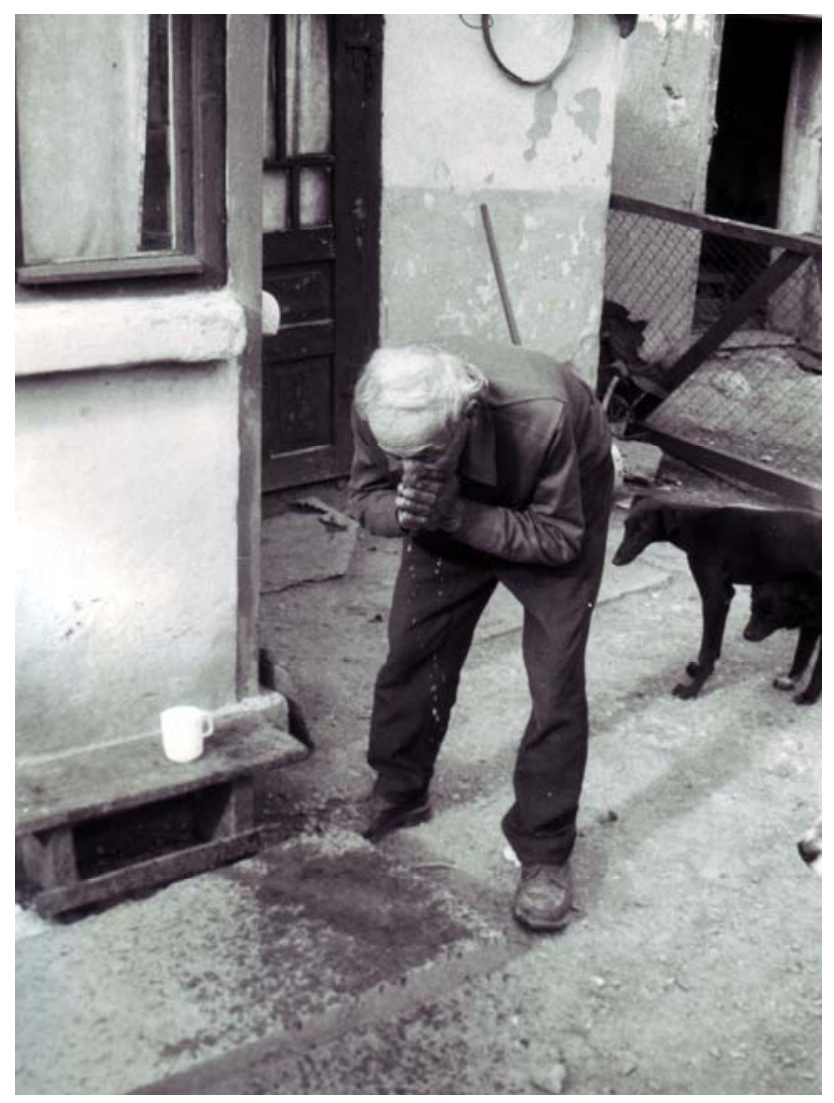

Figure 4. Washing (Transcarpathia). Photo: Z. Szabo, 2002

\section{Archaic peasant hygienic practices}

Clean - this is one who has no dirt on his body, no lice and mites. Smell does not matter.

\section{Hygiene products:}

1. Use of natural water sources, excavated wells, economical water consumption.

2. There is no specific place, wooden vessels are used.

3. Homemade soap, rags, potash, sand, wood ash.

4. General homespun towels, rags for wiping feet, old sheets.

5. Fat, milk, butter, honey / magic.

Characteristic features of body hygiene: Use of improvised means, proximity to nature, ecological compatibility. Magic and ritual features, the important role of women.

To sum it up: archaic peasant methods of hygiene and water use depend on the natural environment and local climate, are in harmony with seasonal weather changes, in a word, close to nature. The volume of water consumed is minimal, hygiene products decompose in the soil, i.e. keeping the body clean does not affect the local ecology: water after washing or shaving does not damage the environment. The 
concept of "garbage" is alien to the traditional peasant mentality: they do not throw anything away; all things are recycled ${ }^{18}$.

II. Hygienic practices at the dawn of village modernization (early twentieth century - the 1960s).

The dissemination in the peasant environment of hygienic practices, characteristic of the urban population, has become part of the process of capitalist modernization. It originates at the turn of the nineteenth and twentieth centuries and is gradually gaining more and more wide circles of the rural population, which partly imitates the townspeople, but is increasingly changing itself, under the influence of school education, hygiene promotion and improvement of the quality of health care. Generations brought up between the two world wars and until the 1960s adhered to these rules until death (Figure 5).

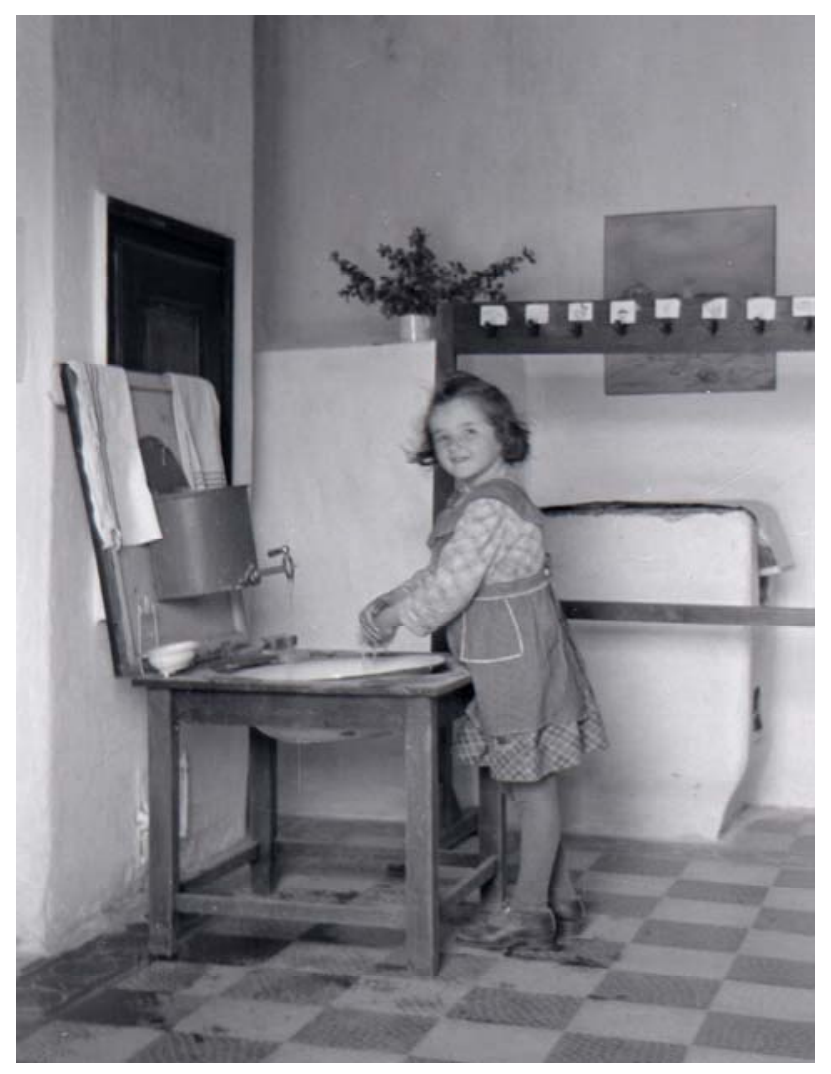

Figure 5. School washbasin (Alföld). Photo: Francisci, 1952 Courtesy of the Hungarian Ethnographic Museum (Budapest)

${ }^{18}$ Veronica Murányi wrote a brilliant study on garbage collection, in which, on the basis of the material of the Romanian village of Ghimeş inhabited by Hungarians (in Hungarian called Gyimes), compared, on the one hand, traditional peasant, on the other - modern mentality and behavior. See: Murányi V. A ház szennye, szemete. Hulladékkezelés Gyimesközéplokon az ezredforduló után. Tiszta sorok. Tanulmányok a tisztaságról és a tisztálkodásról; Szerk. K. Juhász. Budapest, 2009, pp. 188-203. 


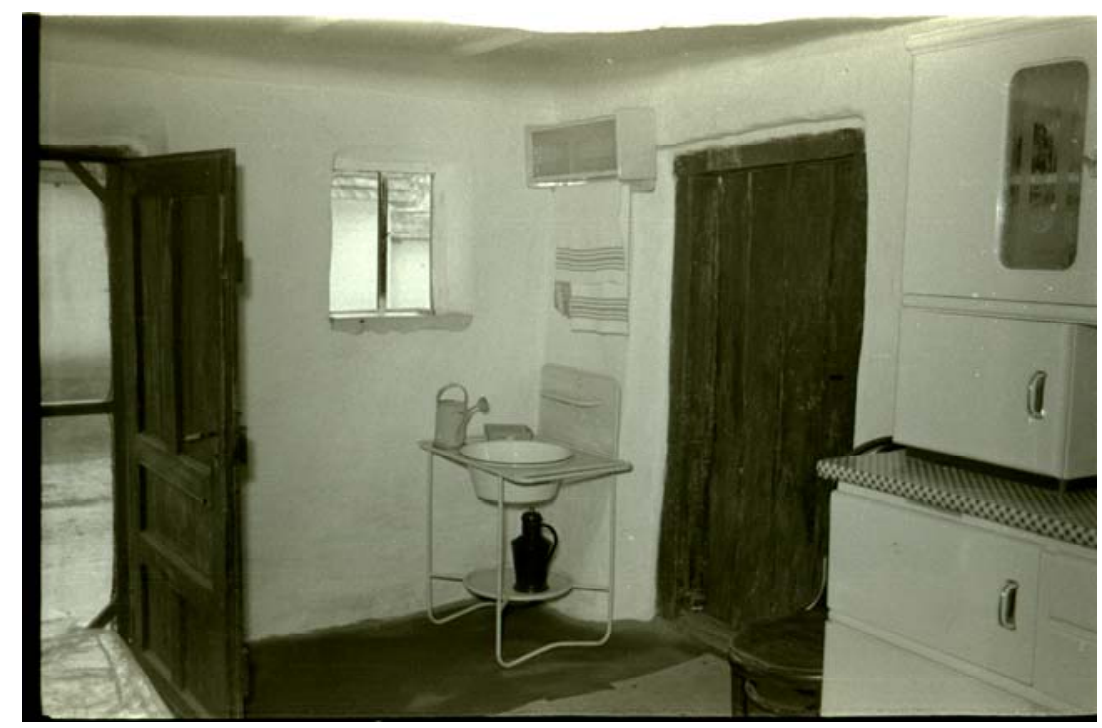

Figure 6. Typical wash-corner in the kitchen. Photo: B. Molnár.

Curtesy of the Hungarian Ethnographic Museum (Budapest)

In this system, a person is clean if dirt isn't seen. Thanks to health and preventive measures in schools they begin to monitor at least the cleanliness of children's nails, neck, ears. The smell of the body still does not excite anyone, on the contrary, the peasant environment condemned the fragrance of perfume, the use of cosmetics was not welcomed. Kitchens are stoked in "white", a typical corner for washing appears, it is equipped with tools that were produced in large quantities by industry, or manufactured in an amateur way according to their samples (Figure 6).

Daily hygiene procedures consisted of morning washing, washing hands before meals and after dirty work, in the evening - pouring above the waist and washing the feet. Thorough washing, which happened only once a week (on a Saturday or Sunday), required serious preparation, like carry and heat water, which for hygiene needs was required more and more. This became possible, on the one hand, due to the increase in the number of drilling wells and artesian wells for general use, on the other hand - changes in washing technique and its regularity. Old reservoirs for transporting water (buckets, water bottles) in a number of places (primarily in Alföld) are replaced by enameled or aluminum cans, the lid of which could serve as a drinking bowl (Figure 7). These cans with handles could not only be carried in hands, but also carried on a bicycle (in a special basket, fixed on the trunk on both sides), which greatly facilitated water supply. Meanwhile, the water reserves, as in the previous model, were made exclusively for one day, which still required a saving mode. So, the whole family took turns washing in the same water (first children, then the father, then the mother of the family), then they did laundry in it and finally used it for technical purposes (rinsing, rubbing). 


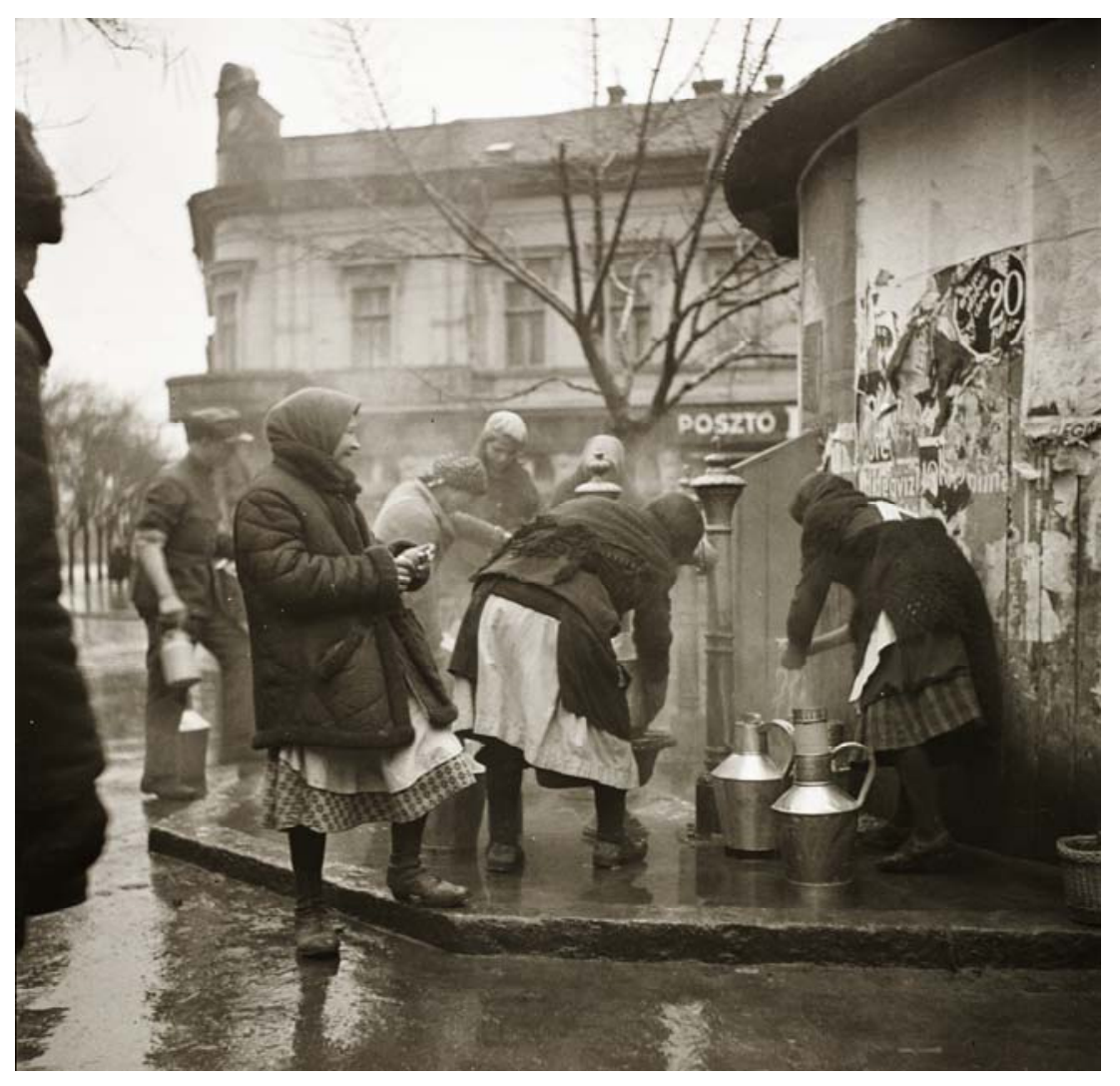

Figure 7. Fountain Anna in Szeged, 1936. Photo: Ebner.

Online photo archive "Fortepan", No 83806

Until the late 1950s of the twentieth century, they preferred to wash themselves with home-made soap, toilet soap ("Caola" or "Elida") sold in stores was mostly bought by girls for marriage and young women (and those did it only on holidays). Since the 60s of the twentieth century, people engaged in manual labor and their family members washed themselves with the soap of "Baba" or "Kék-Vörös" soap makes. It was this soap that was most popular in those years. Until the late 1950s in the summer they washed their heads every two to three weeks, in the winter - even less often, sometimes every few months. At the turn of the 1950-1960s young people started using shampoos. Cleaning the teeth has not yet turned into a daily habit: it was done from time to time, in several places for the whole family there was one toothbrush, some brushed their teeth, pouring soda, salt or tooth powder on the index finger.

Hygienic practices in the rural environment at the dawn of modernization

Clean is someone on whom dirt is not seen, who has clean, trimmed nails, who doesn't reek.

\section{Hygiene products:}

1. Use of natural water sources, excavated and drilled wells, careful use of water. 
2. Wash basin, toilet bowl (also for representative purposes).

3. Homemade soap, on special occasions - shop soap and shaving soap.

4. A common towel, separate towels for children, top and bottom of the body, a towel for the baby.

5. Face cream, baby cream, talc, cologne.

Characteristic features of body hygiene: partly self-made, close to nature, ecofriendly means. Under the influence of sanitary and hygienic education, which taught that cleanliness is a moral duty, magical and ritual traits recede into the background. The role of women is still high, but the responsibility of the individual is already emphasized.

Consequently, it can be said that due to the spread of hygienic norms and practices, the consumption of water in the village, which entered the modernization path, increased slightly, because of water saving and the use of environmentally friendly hygienic means, this practically did not increase the "ecological footprint" (the extent of human exposure to habitat). At the same time, the use of toilet soap and industrial shampoo or the habit of brushing your teeth already indicate a gradual transition to a new model.

III. Hygienic practices in the village during the period when a peasant converted into an agricultural worker (1960-1980).

Despite the appearance of bathrooms in Hungarian villages in the process of modernization in the second half of the $1960 \mathrm{~s}$, the lack of infrastructure did not lead to a radical change in hygiene practices, but rather created a transitional situation. It is known, that in the period between the two world wars, representatives of the village intelligentsia (doctors, teachers), small entrepreneurs and wealthy landowners arranged in their homes bathrooms according to the urban pattern: the water was supplied by a manually operated water tower and entered the ceiling storage $\operatorname{tank}^{19}$. In the 1950s and 1960s this was the solution for those who, despite the lack of public water supply, wanted to bring water to their homes. However, the majority still carried water from a personal well or a water intake column. The success of the communal water supply to the dwellings relates to the construction of so-called "minihydrotechnical constructions" which, with the help of a "hydroglobus" (located at the height of a ball-shaped tank), supplied a dense network outdoor water pumps with clean water (Figure 8).

19 Juhász K. A tisztálkodás és szépségápolás átalakulása falun az 1960-1970-es években. Múltunk, 2008, 53. 3, pp. 109-121. 


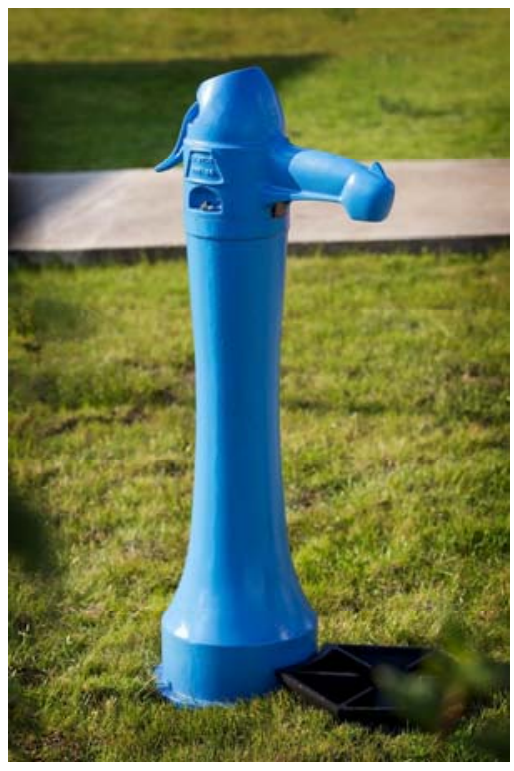

Figure 8. Typical outdoor water pump 1960s.

Although in the socio-political and economic sphere, after the communists came to power in 1948, radical changes took place, sanitary and hygienic educational propaganda operated with old (bourgeois) concepts, known even under the previous regimes. The difference was observed in the fact that the former authorities considered cleanliness and health a duty of the citizen, communist propaganda called it part of communist morality and struggle with capitalism.

The shared use of towels is gradually becoming a thing of the past, in the villages new types of hygiene products and body care products are started to be used: various kinds of soap, perfumes, hair and skin care, shaving, and baby care ${ }^{20}$. Both in fashion and in hygiene practices, small villages were involved in the process with a delay of several years. Products that appeared in the trading network of large cities were known little and used little in villages, except for the social elite, including younger generations. For daily water treatment and body care in the country, Hungarian goods (soap of "Baba", "Caola", "Kék-Vörös", creams "Baba", "Caola"21) were used, but young women already got the products of the Hungarian cosmetic industry (face cream, powder, lipstick, nail polish, "Camea" hair spray). Under the influence of ac-

20 The urban population acquired these means of care during the period between the two world wars, the villagers started using them only in the 60 s of the 20 th century, replacing the usual homemade means with them.

21 The peasant worldview condemned everything that was considered "excessive" luxury, an exception was made only for cheap baby powders and creams, starting from the 1930s of XX century. Since the cream "Baba" was very fat, the whole family used it: smeared face, hands, body, used as a shave cream and so on. That is why in the 1960s it was given out to workers in "dirty" industries along with soap. Cream "Caola", produced by the Baeder factory, enjoyed universal love, comparable to the modern popularity of the cream "Nivea" in a round jar. It was used only by women, and in the countryside, it got spread only in the 1960s. 
tive propaganda of a healthy lifestyle, more and more villagers daily brush their teeth, with their own toothbrushes and using Hungarian toothpastes "Ovenáll", "Amodent" $"$. This new transitional model of hygiene and body care was accompanied by an increase in water consumption.

Hygienic practices in the village during the peasant transformation in an agricultural worker

Clean is someone with not only visible but also invisible dirt, who doesn't reek, a light fragrance of perfume or cologne can talk about grooming.

\section{Hygiene products:}

1. The use of natural water sources, excavated and drilled wells, a denser network of water pumps connected to "hydroglobes" (water storage), sometimes - domestic water supply, careful water consumption, sewerage has not yet been carried out, instead of it - cesspools.

2. Wash basin, toilet bowl, first bathrooms (often for representative purposes) (Figure 9).

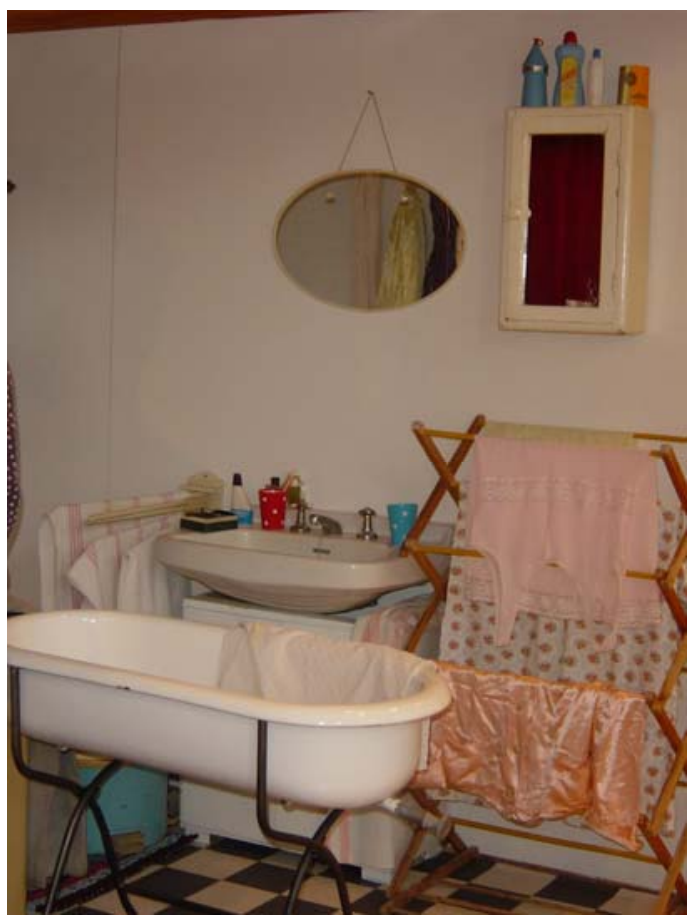

Figure 9. Village bathroom in the 1960s.

3. Shop soap, shampoo, baby bath, shaving soap, shaving cream.

4. Individual towels, at least - on the basis of sex and age, hand towels.

5. Creams for face, hands, baby cream, personal hygiene products of Hungarian production.

22 Toothpaste "Ovenáll" was produced in the interwar period, while "Amodent" is a product of the socialist industry. 
The characteristic features of body hygiene: home-made care products are becoming a rarity, the products of socialist industry are used everywhere, the pollution of the environment is slightly increasing. Work on "socialist" enlightenment and education among peasants and workers in order to "enhance culture", showers in workplaces and baths with thermal water make a revolution in the hygienic practices of the village. Propaganda emphasizes personal responsibility, but the role of women in maintaining cleanness is still high.

In the 1960s in rural areas, collective farms, state farms and other enterprises production showers were installed; as a result of exploratory drilling for oil, the number of thermal baths increased, which were actively used for washing at weekends ${ }^{23}$. There was no longer any need to save water, and gradually a different attitude towards water use spreads among the villagers.

The older and growing under socialism younger generation had very differently attitude towards the volume of water consumed, which served as an occasion for endless conflicts. Older people condemned "wastefulness", while young people considered the old people's water procedures to be outdated, not hygienic. From the point of view of protecting the environment, the truth was on the side of the elderly, since they, following the practices that had been adopted in childhood, still did not leave a litre of dirty water behind the youth not only did not control their water consumption, but also polluted the water with washing and washing-up liquids. Streams of dirty water immediately merged into the soil and surrounding reservoirs, because the sewer system at that time was not brought anywhere. In addition to hygiene procedures, the consumption of water increased due to washing clothes and washing dishes. The dishes used to be washed in a small amount of boiling water and, without rinsing, wiped with a towel, but now it was first washed in water with the addition of detergent, then rinsed in running water. Doing laundry radically changed with the spread of detergents and washing machines. Since doing laundry became easier, it (as well as changing clothes) became more frequent. Synthetic detergents, which replaced the decomposed soil soap and alkali in the soil, together with the increased amounts of dirty water led to greater pollution of the environment.

\section{IV. "Consumer socialism" (from the late 1970s to the 1990s) ${ }^{24}$}

In Hungary, the introduction of a "new economic mechanism" in 1968 led to a gradual reorientation of the economy to market needs. Here the epoch begins, the main features of which were revealed in the 1970s; Hungarian historians and sociolo-

23 Juhász K. Termál- és ökoturizmus-koncepciók Gyomaendrődön. A társadalomtudományi kutatás lehetőségei egy város versenyképességének javításában. Ethno-Lore: a Magyar Tudományos Akadémia Néprajzi Kutatóintézetének Évkönyve, 2014, 31, pp. 261-310.

${ }^{24}$ Valuch T. A hosszú háztól a kockaházig: a lakásviszonyok változásai a magyar falvakban a hatvanas években. «Hatvanas évek» Magyarországon. Tanulmányok; Szerk. J.M. Rainer. Budapest, 2004, pp. 386-407. 
gists call it "consumer socialism" or, more grossly, "goulash-communism", the "most cheerful barrack" of the socialist camp. This time is characterized by a positive reevaluation of consumption, preferential attention to consumer behaviour. Despite the unfavourable processes in the world economy, the country's government administration headed by J. Kadar at the price of state loans tried to ensure the growth of living standards of the population. For this reason, under conditions of relatively low wages, work permits and private entrepreneurship were allowed, which increased the purchasing power of citizens. The desire to increase the country's currency reserves went hand in hand with openness towards the West, from where not only the economic crisis came, but - along with the currency - western consumer culture penetrated. The housing and construction industry was on the rise, the provincial infrastructure was developing and, as a result, so as the number of actually used bathrooms.

Since the mid-1970s the Hungarian citizens have got opportunities for shopping tourism: first to the socialist countries, from the 1980s to the capitalist countries. At the same time, the number of foreign-made goods on the shelves of Hungarian stores grew. Among the cosmetic and hygiene products, soap "Fa", products of "Rexona" and deodorants "Impulse" enjoyed unprecedented popularity. Hungarian industry, with its seven-league steps, was catching up with the world level of production, which was felt both in the quality of production and in the breadth of the used tools in order to of maintain cleanliness and personal hygiene. Famous Hungarian cosmetic brands ("Amo" soap (Figure 10), "Óceán" series, lines of face care products "Fabulon", "HeliaD", cosmetics for children "Gabi", deodorants "Exotic" and "Derby") appear and become popular in the socialist countries. Meanwhile, in the villages soap, cream, deodorants of foreign (sometimes Hungarian) production, and sometimes even empty bottles and boxes, were exhibited as a symbol of social status, not even in the bathroom, but in the living room, to be in sight, and served as a kind of decoration.

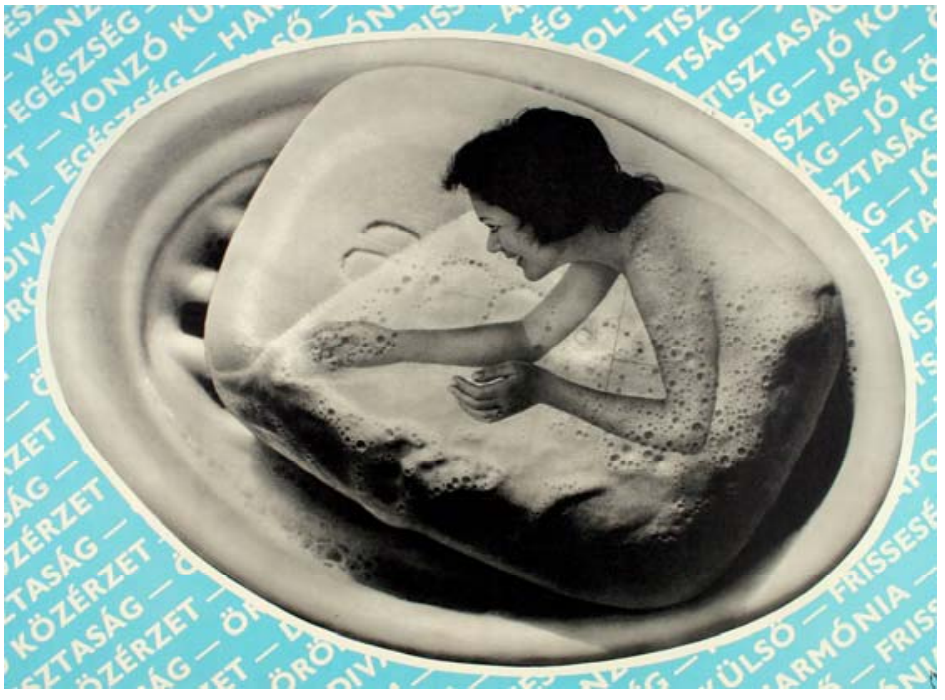

Figure 10. Advertising of toilet soap "Amo" in the late 1970s 
Since the late 70 s of the 20th century, the number of households equipped with running water increased sharply in rural areas, and new houses and apartments were planned exclusively with bathrooms. In those settlements where there was no public water supply, the water was brought into the house from its own well through a submersible pump. Because of the lack of sewage, dirty water drained into cesspools dug in the courtyard, which from time to time were cleaned by sewage machines ${ }^{25}$.

Hygienic practices of the village under "consumer socialism"

Clean is the one who daily bathes (regardless of actual skin contamination), who has a well-groomed appearance, who smells good (uses shampoo or deodorant).

\section{Hygiene products:}

1. Tap cold and hot water, in some places also drainage

2. All houses have a bathroom

3. Means for care and household chemicals primarily of Hungarian production, but there is already import. Along with toilet soap, foam for baths is used, cosmetics for men are distributed

4. Each has his own (terry) towel for daily bath or shower.

5. Along with the Hungarian goods import goods appear. The arsenal of cosmetics expands, it is planned to differentiate care products and decorative cosmetics by age, sex, skin type.

Characteristic features of body hygiene: consumerism is gaining popularity, foreign manufacturers come to the market, Hungarian advertising is developing rapidly. The difference between a village and a city decreases. Hygienic care of the body has become self-evident, it is not considered a moral duty, personal care depends on the individual's fashion and financial capabilities.

Those who lived in village houses with a garden, washed not only in the bathroom, but also in the old-fashioned way. The shower and toilet were installed in the "summer kitchen" 26 or at the exit from the house to the backyard and were used for quick rinsing during gardening, harvesting, summer kitchen work. If there was an automatic washing machine in the bathroom (Figure 11), the old one - with the squeegee rollers - and the centrifuge went to the summer kitchen, and were used to do laundry in the courtyard in the summer.

25 They were trucks equipped with a thick pipe and a pump, which pumped out sewage from a cesspool or a toilet located in the courtyard.

${ }^{26}$ In the Hungarian villages, the so-called summer kitchen is widespread, which appeared at the turn of the $19^{\text {th }}-20$ th centuries. It was located at the back wall of the house or in a small building opposite the entrance to the house. The idea was to free the house of dirt and disorder accompanying work in the kitchen. 


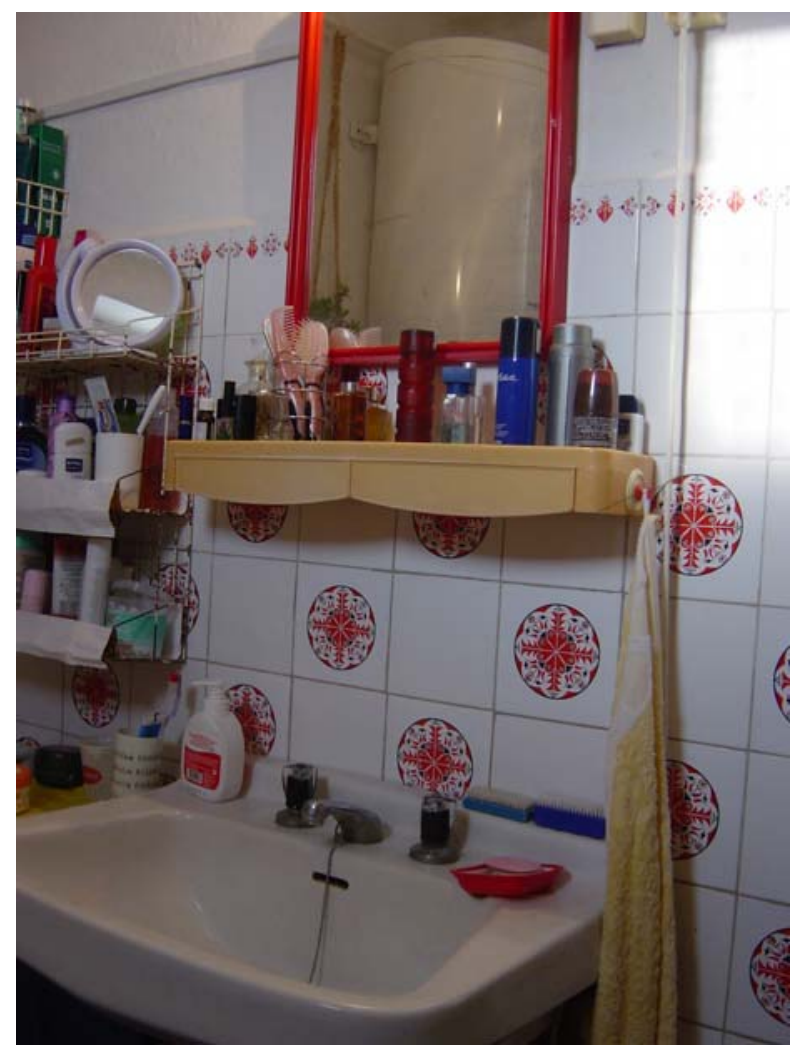

Figure 11. Rustic bathroom in the 1980s. Photo of the author

All this was a forced measure, because a limited amount of cesspools required saving in water consumption. It was then that the rural population first encountered the problem of disposing of sewage. Often, after overflowing the cesspool, the dirty water after washing and washing dishes was poured into a street ditch or the nearest natural pond, but then this did not entail serious consequences. Others for the sake of economy used dirty water from the washing machine or after taking the bath again: washed floors or poured into the toilet bowl. It was not considered shameful to wash in the water, in which the child or a member of the family had already bathed. All these practices can still be observed today in remote corners of the country and among older people born before the Second World War.

In general, I can say that during the period of consumer socialism, water use and pollution of the environment significantly grew. In addition, there was still no talk about environmental awareness, nor about a careful attitude to resources. In a socialist society, people are used to the fact that they do not have the ability to make their own decisions, and therefore they are not responsible for protecting the environment. The most cheerful barrack (as Hungary was called in the socialist camp), swept by the fever of consumerism, did not think about it.

$V$. Consumerism (from the 1990s to the present day).

After abandoning socialism and changing the political system in 1989, rural society experienced a process of stratification based on the size of property (not only 
the possession of fertile land) and income. In the 90s of XX century and even more at the beginning of this century, the unhindered spread of the global consumption culture came to the smallest village. Differences in the social position and way of life now flowed not between town and country, but manifested in property relations. The concept of cleanliness, grooming has become truly complex these days. A man in complete confusion has to make a choice in the conditions of an ever-growing supply of funds to care for various parts of the body. In the bathrooms, as colleague ethnographer Kata Jávor's informant remarked wittily, a "revolution of bottles" occurred ${ }^{27}$. In the past, with the help of household soap alone, they washed their bodies, washed their clothes, washed their heads, shaved, but now special means are used for face, hands, hair, intimate hygiene, bathing or showering. Only for washing the head (almost every day), three or four cosmetic tools are used (shampoo, selected according to the type and colour of the hair, balm, nourishing mask, foam, gel, lacquer, etc.). To replace the universal cream "Baba", which used to be suitable for the whole family, now different means for face and body are used to care for infants and problematic skin of adolescents, for women of different ages and men with different types of skin. To look good, now it is not enough to be clean: this concept includes also epilation, make-up, deodorant, perfume, and many people try to approach the ideal of beauty by experimenting on their own body (tattoos, injections of Botox, plastic surgery).

The process of civilization, as Norbert Elias understood it $^{28}$, reached the stage at which a person aspires to destroy any "product" of his biological activity, to erase it from the face of the earth at the moment of its appearance ${ }^{29}$. A modern rustic bathroom, which does not concede anything to the urban one, fully corresponds to this principle. The bathroom used to be a service room for washing face and body, now it has turned into a sanctuary for caring for your own body and at the same time a place where a "legitimate body" 30 is created, ready for presentation to others. This is also indicated by the separation of the toilet from the laundry space (special laundry room). Strictly individual use of towels, own soap, shower gel, shampoo, toothpaste, for wealthier citizens - several bathrooms, washbasins, toilets within a single home indicate the strengthening of a person's own self. As a result, an individual is completely protected from contact with guests or family members through a common sink, toilet bowl and so on.

27 Jávor K. A higiéniai gyakorlat változása az ideák, köztük a saját testhez való viszony tükrében. Zsombó (1977-2007). Tiszta sorok. Tanulmányok a tisztaságról és a tisztálkodásról; Szerk. K. Juhász. Budapest, 2009, pp. 141-158.

28 Elias N. O processe ivilizacii: Sociogeneticheskie $i$ ogeneticheskie ssledovaniya [On the process of civilization: Sociogenetic and psychogenetic studies]. Moscow; St Petersburg: DirektMedia, 2001.

${ }^{29}$ Kapitány Á., Kapitány G. Néhány gondolat a tisztaság szimbolikájáról. Tiszta sorok. Tanulmányok a tisztaságról és a tisztálkodásról; Szerk. K. Juhász. Budapest, 2009, pp. 17-47.

${ }^{30}$ Bourdieu P. A társadalmi egyenlötlenségek újratermelödése. Budapest, 1978, p. 154. 
In Hungary of the twenty-first century with the development of consumerism, depending on buyers' purchasing power, a wide range of goods and services for body care, from elite lines to cheap discount products is offered. Recently, the fashion for "naturalness" (also in different price categories) has spread. In fact, this could contribute to improving the environmental situation, but while eco-friendly detergents and perfumes constitute an insignificant share of consumption, the material in which they are packed, causes damage that is not inferior to what is done by packages of "ordinary" products.

Hygienic practices of the village in the era of consumerism

Clean is someone who is groomed from head to toe (here also includes hair removal, manicure, pedicure, hairstyle, perfume, women - make-up).

\section{Hygiene products:}

1. Tap water, sewage.

2. Bathroom (there can a few be in the house, a shower, a bidet, design matters).

3. Wide arsenal of means for washing body and face: for every age, sex and different parts of the body (toilet soap, liquid soap, bathroom foam, alternative care products).

4. Each family member has their own towel, hand towel, bathrobe.

5. Cosmetics for every age, sex and different parts of the body.

The characteristic features of body hygiene: the use of bathroom, running water and sanitation have become self-evident. All new (artificially warmed up) requirements for body care. The difference between town and country is lost. A medical component (cosmetic clinics, pharmacy cosmetics), as well as a return to natural materials (biological and chemical-free products) is becoming a new one. The pollution of the environment, which occurs in the process of caring for the body, reaches an unprecedented scale.

The concept of cleanliness and cult of a well-groomed body, promoted by consumerism, inflict damage on the environment in previously unseen scales and even harm human health (skin allergies, etc.). Everyday washing of the body and head leads to a high-water intake. The modern wasteful system of municipal water supply and sanitation increases tenfold the scale of pollution. Most of the drinking water flowing from the tap is not spent on cooking and drinking, but on washing, doing laundry and draining the water in the toilet. In addition, after consuming all the dirty water along with the feces is poured into the sewer pipe, from there it enters the treatment facilities and only then returns to the natural environment (Figure 12).

A person of a culture of consumption - even if guided by good intentions - has no idea of the difficulties and cost of water supply, waste processing and wastewater treatment. A modern consumer, leaving mountains of garbage and streams of dirty water every day, finds out from the bill every two months how much water he consumed and how much it cost him. 


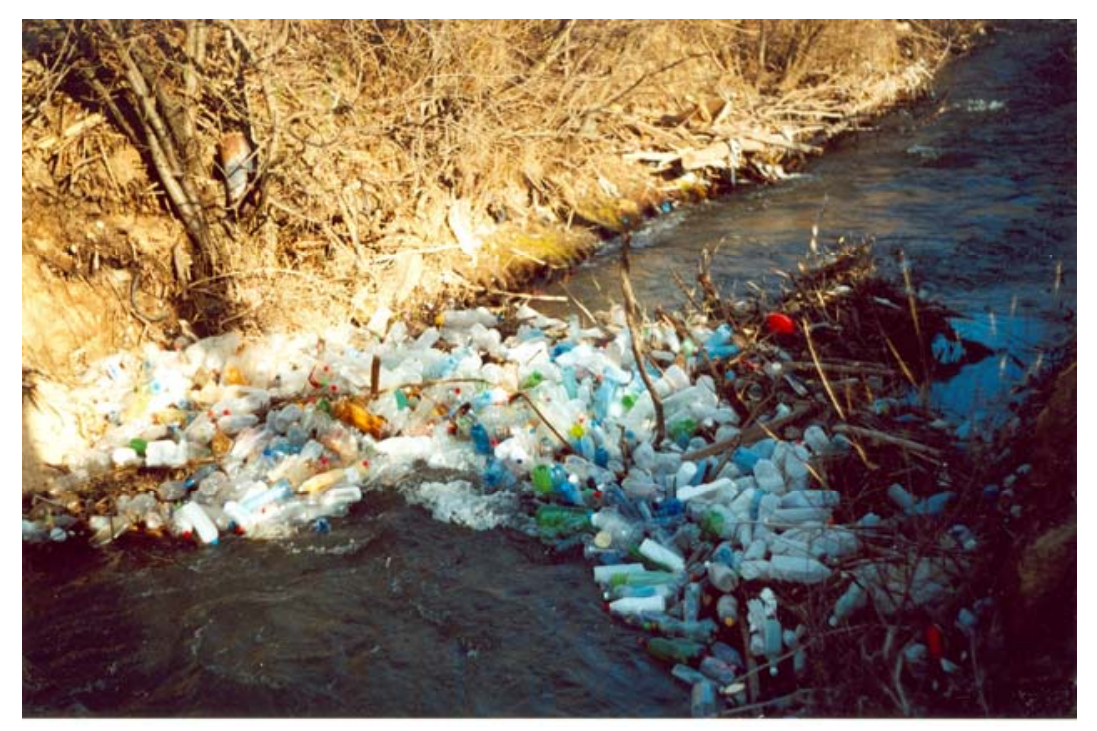

Figure 12. Ditch on the outskirts of the Romanian village with the Hungarian population of Ghimeş (in Hungarian - Gyimes), 2002. Photo by V. Murányi

\section{Conclusion}

Summarizing the changes considered in the article, it is necessary to state the following. In the traditional peasant way of life, the elaborated order of economical use of water for hygienic purposes was developed thoroughly, as a result of which man lived in harmony with the environment for centuries. Bourgeois modernization and the wide spread of consumerism have put an end to harmony: in order to match the market dictated by the ever-new and artificially imposed hygienic standards (ideals), mankind, in pursuit of a well-groomed body, uses more and more water and chemicals, non-compostable packaging materials. In the end, we are getting cleaner, while the environment is getting dirtier.

What conclusions can we draw from a brief ethnographic sketch presented to the attention of the reader? What suggestions can we formulate?

Of course, we are not talking about returning to the archaic peasant way of life. But if you analyze the basic principles, several good thoughts may come to mind:

1. We will be conscious and not indifferent! In a close to nature peasant lifestyle, a person knew from his own experience how hard it was to extract the water for daily hygiene procedures, and therefore spent it carefully, to maintain personal hygiene. In the peasant picture of the world there was no room for rubbish, all wastes were used to the last drop for the second time, which meant $100 \%$ recycling. If at any time of the day and night the water flows from the tap, and the sewage is instantly washed into the sewage system, we do not directly feel, as it used to be "the hard way", neither water extraction nor pollution, because we learn about the negative impact on the environment not from the first hands, in the most general terms.

The solution lies on the surface: people need to constantly be reminded that they pollute the environment, of the so-called ecological footprint and how much of their money goes to their own cleanliness and comfort. There is a technical opportunity to 
equip the apartments with appliances that would show how much one bath, one shower, one wash, etc. cost.

Multiple changes in hygiene practices over the past hundred years show that a change in the prevailing worldview is possible, but will require a whole system of activities and serious civic engagement. Sooner or later these efforts will bear fruit.

Recent research indicates the same: even in the smallest villages, more and more people are saying that they are trying to conserve water and use environmentally friendly detergents. Today, you can buy everywhere - and this product is in increasing demand - the usual laundry soap, soda (sodium carbonate) and soap nuts.

It is clear that the producers and sellers who are chasing profit are not easily convinced of the harm and uselessness of their new miracle means, but it is striking that the words "bio-", "organic", "natural" are in fashion, even if in most cases there is no question of protecting the environment.

2. Fundamental rebuilding of the water supply and sewerage system. The above considerations and other similar proposals, while the present sanitary-hygienic system exists, will not solve the problem. In this context, the concept of water management and wastewater treatment proposed by the Belgian scientist of Hungarian origin Josef Országh, published by him in $1992^{31}$, is interesting. The idea of the proposed system is that both water supply and water treatment should be organized so that the cycle of water and the incoming in its composition of nitrogen, carbon and phosphorus, as far as possible, was not interrupted ${ }^{32}$. Those who wish can get acquainted with this fully self-sufficient, non-waste water supply method developed for a family or

31 Országh J. Approche systémique du problème de traitement des eauxusées domestiques. Tribune de l'eau (CEBEDEAU), 1992, no. 6, vol. 45, pp. 89-94.

32 This can be achieved by guaranteeing the following conditions. Available at: https://www.eautarcie.org/hu/02c.html, retrieved 15.10.2017: Grey (soap) and black (contaminated with faeces) water should be collected separately and processed so that useful resources are extracted from grey and black water. These waters become unclean and present a danger to the environment only after they are mixed. Water containing human or animal excrement must be cleaned, it is strictly forbidden to pour it into the ground in a natural body of water or allow infiltrating the soil. This water must be processed together with materials rich in nitrogen or phosphorus, cellulosecontaining materials of natural origin. The primary goal of processing black water is not to fight the danger posed by faeces, but to restore humic soil reserves and revitalize the living world. At this level, the water content of elements such as nitrogen $(\mathrm{N})$, phosphorus $(\mathrm{P})$ or potassium $(\mathrm{K})$ is less important than the place they occupy in molecular systems of humic substances.

Grey (soap) water is a resource that can and should be used for watering agricultural land or filling underground waterways. It is necessary to avoid dirty water (even after cleaning) in natural water bodies. To treat grey water, you should use natural light and the cleaning potential of the soil. In the sphere of water supply it is necessary to put the quality of water in dependence on the destination. For the integrated operation of all water resources, their use (including rainwater) must be subject to uniform legal regulation. Admittedly, except for drinking and cooking, for all other economic purposes, water that is safe in chemical composition can be used, even if it does not meet drinking water standards. 
apartment building on the Internet, there are also a technical description and references to implementation experience in seven European languages ${ }^{33}$.

Responsibility is in the hands of those who make decisions, control is in the hands of society, and then a change in the outlook will become inevitable, and our cleanliness does not lead to more and more pollution of the planet. Let's hope that by joint efforts we will overcome inertia and achieve positive changes. At stake is our life.

\section{References}

1. Antropogén ökológiai változások a Kárpát-medencében; Szerk. B. Andrásfalvy, G. Vargyas. Budapest: L'Harmattan, 2009.

2. Bausinger H. "Párhuzamos különidejüségek". A néprajztól az empiriku skultúratudományig. Ethnographia 100, 1989, pp. 24-37.

3. Borshosh B. Reki, blata i zemedelski zemi. Izsledovatelski perspektivi za ekologichnata istoriya na Ungariya chrez primeri ot Bodrogk'oz, Severoiztochna Ungariya. B'lgarski folklore, 2011, T. 37, no. 1, s. 110-127.

4. Borsos B. Rivers, Marshes and Farmlands. Research Perspectives on the Ecological History of Hungary through Examples of Bodrogköz (NE-Hungary). Hungarian Studies, 2009, vol. 23, no. 2, pp. 195-210.

5. Bourdieu P. A társadalmi egyenlötlenségek új ratermelödése. Budapest: Gondolat, 1978.

6. Campbell E., Lassiter L.E. Doing ethnography today: Theories, methods, exercises. West Sussex: Wiley-Blackwell, 2015.

7. Csiffáry G. Régi magyar fürdővilág. Budapest: Helikon, 2004.

8. Elias N. O processe civilizacii: Sociogeneticheskie i ogeneticheskie ssledovaniya. Moscow; St Petersburg: Direkt-Media, 2001.

9. Füzes E. Kutak táji típusai. Magyar Néprajzi Atlasz IV; Szerk. J. Barabás. Budapest: AkadémiaKiadó, 1989, pp. 276-281.

10. Gerbershtejn S. Zapiski o Moskovii. [Nots on Muscovy]. Moscow: Nauka, 2008. T. 1. 774 p. (Pamyatniki storicheskoj ysli [Monuments of Historical thought]). (In Russian)

11. Hanák P. Magyarország társadalma a századforduló idején. Magyarország története 1890 1918; Szerk. P. Hanák. Budapest: Akadémia Kiadó, 1988, pp. 403-516.

12. Jávor K. A higiéniai gyakorlat változása az ideák, köztük a saját testhez való viszony tükrében. Zsombó (1977-2007). Tisztasorok. Tanulmányok a tisztaságrólés a tisztálkodásról; Szerk. K. Juhász. Budapest: L’Harmattan, 2009, pp. 141-158.

13. Juhász K. Body - Identity - Society: Concepts of the Socially Accepted Body in the 20th

Century Hungarian Rural Areas. Acta Ethnographica, 2016, vol. 61, no. 2, pp. 283-312.

14. Juhász K. Meg is mosakodjál! Higiénia a 20. századi falun. Have Wash! - Hygiene in the 20th Century Village Szentendre: Szabadtéri Néprajzi Múzeum, 2006.

15. Juhász K. Termál- és ökoturizmus-koncepciók Gyomaendrődön. A társadalomtudományi kutatás lehetőségei egy város versenyképességének javításában. Ethno-Lore: a Magyar Tudományos Akadémia Néprajzi Kutatóintézetének Évkönyve, 2014, 31, pp. 261-310.

16. Juhász K. A tisztálkodás és szépségápolás átalakulása falun az 1960-1970-es években. Múltunk, 2008, 53, 3, pp. 109-121.

17. Juhász K. Zapah tela i aromat chistoty v kul'ture obitatelei "samogo veselogo baraka": Vengriia, 1960-1989 gody [The Smell of the Body and the Fragrance of Cleanliness in the Culture

${ }^{33}$ Available at: https://www.eautarcie.org/index.html (retrieved 15.10.2017). 
of the Inhabitants of the "Most Cheerful Barrack": Hungary, 1960-1989]. Teoriia mody, 2013, no. 26, s. 339-363. (In Russian)

18. Juhász K., Szabó Z.G. A hidrogeológiai viszonyok és a vízhasználat összefüggései, különös tekintettel a Balaton-felvidék településeire. Tiszta sorok. Tanulmányok a tisztaságról és a tisztálkodásról; Szerk. K. Juhász. Budapest, 2009, pp. 48-65.

19. Kapitány Á., Kapitány G. Néhány gondolat a tisztaság szimbolikájáról. Tiszta sorok. Tanulmányok a tisztaságról és a tisztálkodásról; Szerk. K. Juhász. Budapest: L’Harmattan, 2009, pp. 17-47.

20. Kósa L. A magyar néprajz tudománytörténete. Budapest: Osiris, 2001.

21. Kósa L. Paraszti polgárosulás és a népi kultúra táji megoszlása Magyarországon (18801920). Debrecen: KLTE, 1990.

22. Lajos V. Testek - tisztaság - modernitás. Kulturális és társadalmi összefüggések Moldvában a «báje» kapcsán. Tiszta sorok. Tanulmányok a tisztaságról és a tisztálkodásról; Szerk. K. Juhász. Budapest: L'Harmattan, 2009, pp. 159-171.

23. Murányi V. A ház szennye, szemete. Hulladékkezelés Gyimesközéplokon az ezredforduló után. Tiszta sorok. Tanulmányok a tisztaságról és a tisztálkodásról; Szerk. K. Juhász. Budapest: L'Harmattan, 2009, pp. 188-203.

24. Országh J. Approche systémique du problème de traitement des eaux usées domestiques. Tribune de l'eau (CEBEDEAU), 1992, vol. 45, no. 6, pp. 89-94.

25. Táj és történelem - Tanulmányok a történeti ökológia világából; Szerk. A.R. Várkonyi. Budapest, Osiris, 2000.

26. A táj változásai a Honfoglalás óta a Kárpát medencében: a Gödöllön 1996. június 24-26.án megtartott tudományos konferencia kiadványa; Szerk. Gy. Füleky. Gödöllö: GATE MSZKI, 1997.

27. Tátrai Zs. Aranyos víz szótlan víz. Tanulmányok a tisztaságról és a tisztálkodásról; Szerk. K. Juhász. Budapest: L’Harmattan, 2009, pp. 271-293.

28. Tokarev S.A. Istoriya russkoj ehtnografii (Dooktiabr'skij period) [History of Russian Etnography (Pre-revolution period)]. Moscow: Nauka, 1966. (In Russian)

29. Tokarev S.A. Istoki ehtnograficheskoj nauki [Origins of Etnographic Science]. Moscow: Nauka, 1978. (In Russian)

30. Valuch T. A hosszú háztól a kockaházig: a lakásviszonyok változásai a magyar falvakban a hatvanas években. «Hatvanas évek» Magyarországon. Tanulmányok; Szerk. J. M. Rainer. Budapest: 1956-os Intézet, 2004, pp. 386-407.

31. Viz és társadalom Magyarországon a középkortól a XX. század végéig; Szerk. G.K. Horváth. Budapest: Balassi, 2014.

32. A víz kultúrája; Szerk. E. Bartha, R. Keményfi, V. Lajos. Debrecen: Debreceni Ehyetem Néprajzi Tanszék, 2010. (Studia folkloristica et ethnographica. 55).

33. Wernher G. De admirandis Hungariae aquis hypomnemation. Sine dato et loco. 20 p. Available at: http://digital.onb.ac.at/OnbViewer/viewer.faces?doc=ABO_\%2BZ103578602

For citation: Juhász Katalin Pollution for cleanliness? Lessons from an ethnographic research on the rural use of water for hygienic purposes. Historia provinciae - the journal of regional history, 2018, vol. 2, no. 1, pp. 29-54. DOI: $10.23859 / 2587-8352-2018-2-1-3$ 